\title{
KARST IN SILICEOUS ROCKS THE SPELEOTHEM MEDIUM OF FINGER FLUTINGS AND ITS ISOTOPIC GEOCHEMISTRY
}

\author{
Robert G. Bednarik*
}

ABSTRACT

\begin{abstract}
The isotopic geochemistry relating to the re-precipitation of calcite in caves is considered, in terms of its theory, natural manifestations, and relationship with questions of radiometric dating of carbonate speleothems. Specific forms of such deposits are considered, together with the various modification processes they are subjected to. More specifically, particular forms of rock art found within, as well as on or under, such deposits are examined, such as finger flutings commonly found in caves of Europe and Australia. Some of the variables relating to their occurrence are elucidated, their preservation and possible dating is reviewed in the light of these factors, and new radiometric data from South Australian caves are introduced and discussed.
\end{abstract}

\section{INTRODUCTION}

Finger flutings (Bednarik 1986; sillons digitales, Drouot 1976) are a specific type of rock art occurring only in caves, and found so far in two world regions. One is southern France and northern Spain, the other Australia and Papua New Guinea (Bednarik 1984, 1985, 1986, 1990; Ballard 1993). At most of the sites of finger flutings, almost fifty of which I have examined, the former, now often 'fossilized' mondmilch (montmilch, moomilk, Bergmilch, etc.; Bates and Jackson 1987; Fischer 1989) bearing markings is of the speleothem (for definition see Moore 1952) type (i.e. reprecipitated), but states of preservation differ profoundly between different sites, and often even within an individual site. The finger flutings, usually occurring in sets of three or four subparallel finger markings, were made by people who drew the tips of the fingers of a hand over a then soft calcareous cave deposit which has in most cases since become fossilized and calcified. The original deposit is often sufficiently well preserved to still be recognizable; it has usually been modified by natural processes, but even then the medium appears to have been soft and pliable at the time the finger flutings were produced. I intend in this paper to examine the nature of this medium, and to determine whether any archaeologically or speleologically significant deductions can be made from it.

If we wish to determine the merits of a geomorphological and geochemical examination of the medium of ancient finger markings, of dating clues derived from it, and of correlating these data with other information, we need to acquaint ourselves with the nature of speleothems, with the effects of modification processes on them, and with the significance of different states of preservation.

\footnotetext{
* International Federation of Rock Art Organizations (IFRAO), P.O.Box 216, Caulfield South, Victoria 3162, Australia
} 


\section{CARBONATE SPELEOTHEMS}

Speleothems result from the responses of particular dissolved rock constituents to atmospheric/hydrospheric condirions in a cave space. They are formations of precipitated compounds such as chlorides (Goede et al. 1992), nitrates, sulphates (James 1991) and most importantly - carbonates. Calcite, dolomite and aragonite generally form carbonate speleothems. They occur in a number of modes, for example as the familiar stalactitic growths, as dripstone curtains, helictites, straws, cauliflower formations, and as cutaneous flowstone formations of various forms. Consisting usually of comparatively pure calcite deposited in crystal form, the size of these crystals and their mode of arrangement and spacing may differ substantially (Dreybrodt 1988). They may be massive and densely packed, or they may be very small and widely spaced, rather like the minute water crystals of snow flakes. These deposits are generally precipitated from calcium bicarbonate solution.

The ability of water to hold carbon dioxide in solution is related to factors such as temperature, turbulence and pressure. Pressure changes dramatically when the bicarbonate solution reaches the ceiling of a cavity. While travelling within the rock's interstitial spaces, the solution is subjected to the quite considerable pressure of the closed system. The cave space, however, experiences atmospheric pressure and this causes the release of surplus calcite as the solution emerges in the cave. It will be in oxygenous isotopic equilibrium with the water if the rate of loss of carbon dioxide is sufficiently slow to maintain the equilibrium between the bicarbonate ions and the aqueous carbon dioxide. If, however, the rate of loss of carbon dioxide from the solution is so rapid that isotopic equilibrium cannot persist between the bicarbonate ions, the aqueous carbon dioxide and the water, a kinetic isotopic fractionation will occur between them and will be reflected as a simultaneous enrichment of $13 \mathrm{C}$ and $18 \mathrm{O}$ in the calcite precipitated (Mills and Urey 1940; Craig 1953; Franke and Geyh 1970; Goede et al. 1982; Hendy 1971; Milliman 1974: 7-12).

Mondmilch occurs usually as a precipitate of an initially pure-white deposit of calcium carbonate whose consistency ranges from downy soft - offering no more physical resistance than freshly fallen snow - to being a pasty or clayey, dense suspension of calcium carbonate in water. The very substantial pores formed by its lattice of minute calcite crystals (which look rather fibrous under the microscope) usually contain much water, often over fifty per cent of the total mass (this represents almost seventy-five per cent of volume).

Carbonate speleothems are sensitive palaeoclimatic indicators (Hendy and Wilson 1968), and are important to dating attempts where the medium of petroglyphs happens to be a speleothem, or where rock paintings, petroglyphs or mining evidence have become covered by such deposits. In Europe, the growth rates, duration of growth, and - within limits - the age of stalagmites have long been determined for a large number of samples by establishing the radiocarbon contents of the precipitates. Often growth rates can be checked by a method similar to dendrochronology, because some stalagmites and pearly formations possess minute laminations caused by annual variations in growth, presumably also related to climatic oscillations (Homann 1969; Geyh and Franke 1970). Baker et al. (1993) have shown, using high-precision thermal-ionization massspectrometry $238 \mathrm{U}-234 \mathrm{U}-230 \mathrm{Th}$ dating, that the luminescence banding in speleothems is indeed annual (cf. Schwarcz 1980; Gascoyne and Schwarcz 1982). 


\section{ALTERATION OF THE FINGER LINE MEDIUM}

Both human and other animal markings on cave walls or ceilings can be significantly modified by later deposition of speleothems. Since these modifications promote misinterpretation of the markings (Bednarik 1991a, 1994a) it is important to consider the modification processes in detail and to try to understand the mechanisms involved. I distinguish five typical classes, illustrated in Figure 1 and described below. Intermediate

Fig. 1 - The typical classes of modifications of finger flutings, depicted schematically: from the top, each section shows the primary rock of the cave roof, on which the mondmilch formed and was marked by fingers.

0 - Fresh (and recent) finger flutings seen in section: examples occur in Rouffignac, Koonalda and Mandurah Caves.

1 - Corrosion has removed some of the surface, resulting in coarsening: Rouffignac, Baume Latrone, Cosquer, Koonalda and New Guinea 2 Caves.

2 - Cutaneous deposit has covered the flutings, but preserved their outline well: Plafond des 'Hiéroglyphes' in Pech Merle, Mooraa, Drop Drop and Nungkol Caves.

3 - Dense speleothem skin has concealed finger flutings and distorted them to appear as narrow grooves: Croze Ö Gontran, Kriton, Prung-kart and Orchestra Shell Caves.

4 - The original mondmilch medium has been gradually dissolved, which exposed the primary rock: Ossuaire in Pech Merle, Yaranda, Gran Gran and Koongine Caves.

5 - Pearly speleothem exudations have formed selectively, avoiding the grooves and accentuating the ridges between them: Malangine, Karake, Snake Hill and Orchestra Shell Caves.

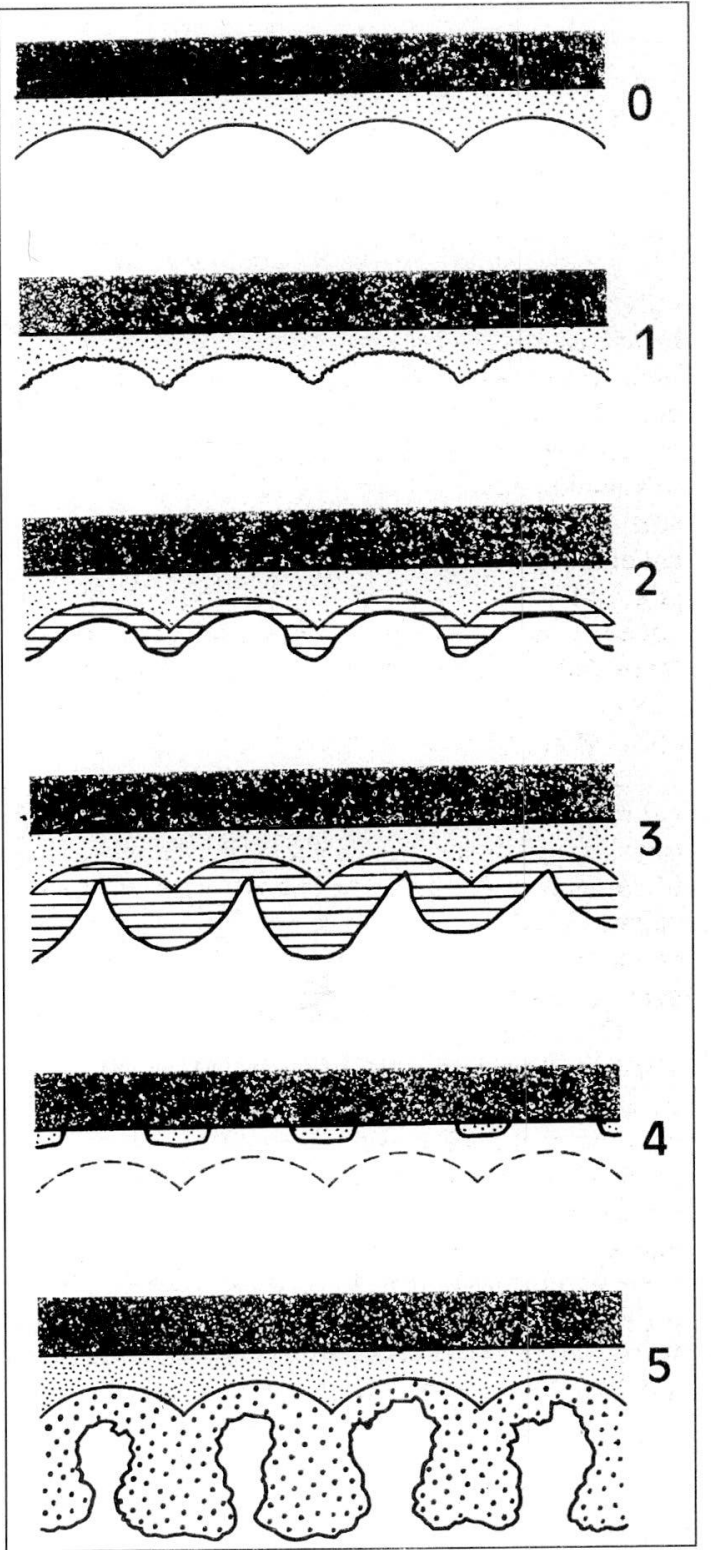


and composite forms of alteration abound and my types are idealized concepts rather than descriptions of the full spectra of such phenomena one observes in the field. At most sites, more than one of these altered forms occurs; nevertheless, the sites I nominate to characterize the respective types are those that seem to typify these classes most readily.

(1) The unmodified, usually recent finger grooves on a mondmilch-covered cave ceiling or wall are smooth, and separated in section by acute, pronounced ridges in the direction in which the strokes were executed (Figure 1-0). Very fine striations can sometimes be discerned within grooves, or transverse 'tear marks' which indicate the direction in which the fingers moved (Bednarik 1986, 1991b). Even if the equilibrium between the factors determining the state of the mondmilch remains fairly stable throughout its history, permitting the deposit to stay soft and somewhat moist, the delicate surface of the precipitate cannot remain totally unchanged over periods of many

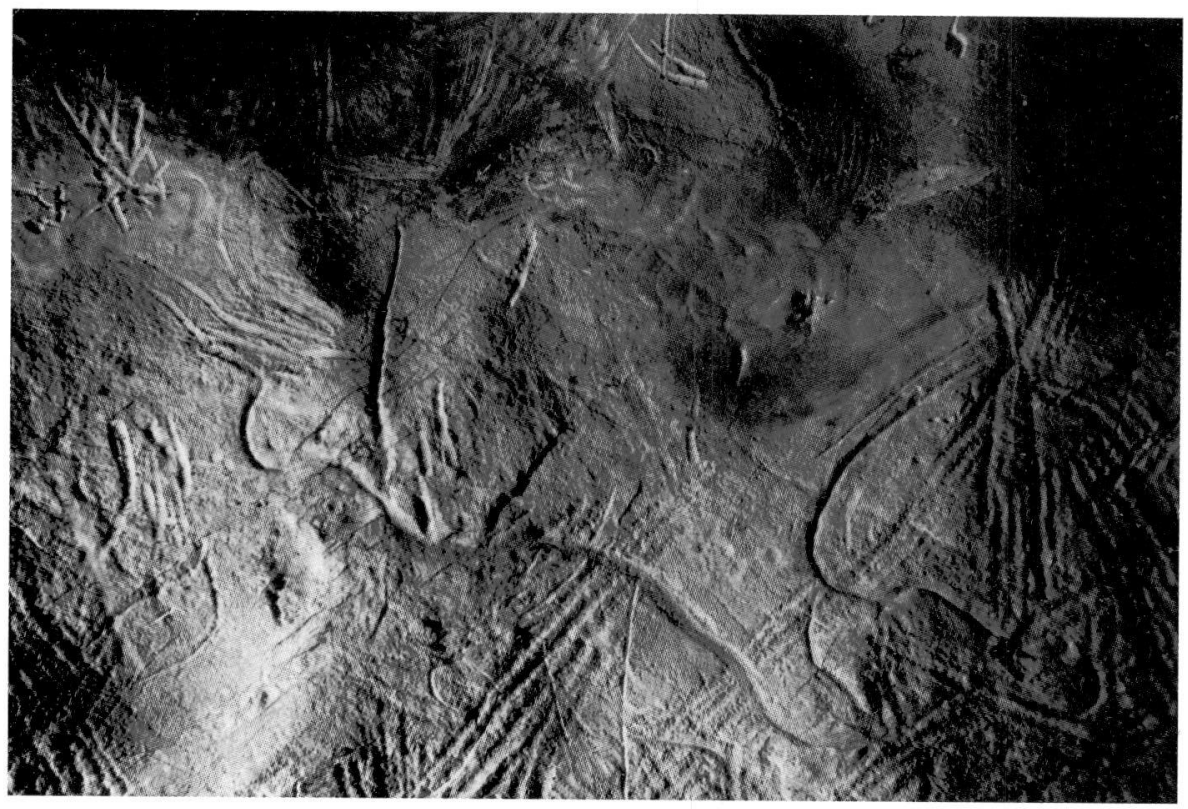

Fig. 2 - Corroded but otherwise perfectly preserved finger flutings, with superimposed and much fresher, further Palaeolithic rock art. Baume Latrone, France.

millennia. Once precipitation has ceased, surface corrosion (probably by the moisture held in the crystal lattice and made aggressive by atmospheric carbon dioxide) will set in and coarsen the texture (Figure 1-1, Figure 2). Also, owing to the persisting softness of the argillaceous deposit, it is susceptible to damage by biological agencies, most notably the abrasive action of bat wings. In deep cave systems, where the speleoclimate was well isolated from external conditions and air residency rates were very high, mondmilch has survived in this mode since the time the lines were made, over many thousands of years.

(2) An uncommon occurrence is the fairly even covering of the finger grooves by a sheet of reprecipitated calcareous deposit, with some thickening at the ridges (Figure 1-2). 
(3) A comparatively dense speleothem skin may conceal all surfaces, but instead of filling in finger lines, sometimes the deposition within the depressions has been inhibited, resulting in narrow grooves of pointed section which may resemble incised cuts (Figure 1-3). In Croze Ö Gontran, France, these occur on both walls and ceilings, which suggests that the deposition process is not influenced by gravity but is perhaps more closely related to the inability of the disturbed mondmilch lattice to convey further migratory carbonates where it was marked.

(4) In contrast to most other types of alteration, the process can be of a reductive kind. The clearest and perhaps most instructive examples of this are found in the Australian site Yaranda Cave and in the easternmost part of the Ossuaire, a section of Pech Merle (Lot, France), where all stages of the process are present: the initial speleothem, resembling the above Type 1, is dissolved slowly (Figure 1-4). The disintegration affects the actual finger lines at a much greater rate, apparently because

Fig. 3 - Section of extreme speleothem growth covering finger flutings: 1 - primary rock of cave roof;

2 - mondmilch, bearing finger fluting; 3 - pearly exudations of carbonate speleothem, the arrangement of which reflects that of the finger flutings; 4 - brown organic stain, partly interstitial and concentrated on the lowest surfaces;

5 - yellowish-white efflorescence of sulphates.

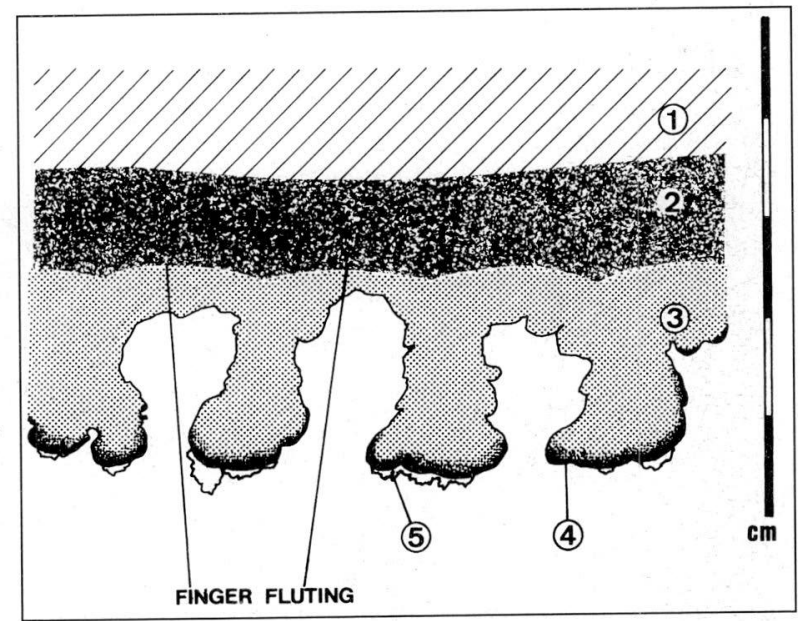

the compressed mondmilch lattice is more susceptible to the dissolving process. The effect resembles the thawing of snow on a road: it melts faster in the vehicular tracks where the snow (i.e. its crystal structure) has been compressed. The white mondmilch is first dissolved in the finger grooves, their course being then indicated by stripes of reappearing primary rock. As the precipitate decays further, its residual arrangements also wane until they completely disappear. Yet they are still perceptible even after the mondmilch is dissolved completely, because a dark film then remains behind - rather like the dark residue one may detect after the spring thaw on the ground. On snow, this residue may consist of dust and other airborne matter formerly dispersed in the snow matrix; in the case of the mondmilch it is of non-carbonate matter, possibly of colloids, small particles and organic matter that had been deposited in the lattice.

(5) A more extreme form of the selective deposition described above in (3) is mostly restricted to ceilings. Distortion ('sagging') evident on similar deposits on sloping surfaces indicates that gravity is involved in the precipitation process. The dominant mechanism in the formation of these exudations appears to be that of selective deposition along ridges, as described above (Figure 1-5; see also Figure 3). 


\section{SPELEOTHEMS IN THE MT GAMBIER ROCK ART SITES}

In 1980 I located a sequence of calcareous speleothem deposits interstratified with a sequence of petroglyphs in Malangine Cave, in the Mt Gambier karst region of South Australia. The art series commences with mondmilch finger flutings, followed by deeply carved, apparently non-iconic motifs (Bednarik 1994b). In the southern part of the cave, the latter generation of rock art precedes the main speleothem deposit, itself bearing shallow line figures which were executed shortly before the deposit matured. Digital fluting occurs mostly in the deeper parts of both Malangine Cave and nearby Koongine Cave, but fortunately for the purpose of studying the rock art sequence, there are some instances of superimposition by later petroglyphs. The petroglyph generations in Malangine Cave are thus sandwiched between laminae of speleothem deposits, as indeed they are at several other sites: in Croze Ö Gontran as reported above, and in the Australian sites Prung-kart (Bednarik and Head 1995), Nung-kol and Kriton Caves. Identification of the finger flutings as the oldest petroglyph element present in these sites, although adequately resolved by the speleothem stratigraphy, finds support in the complete lack of finger markings on the surfaces exposed by the ceiling collapse in Koongine Cave (which also truncated the mondmilch panels), which appears to provide a convenient terminus ante quem for the petroglyph production in that cave. The collapsed mass of rock is now buried under some one or two metres of sediment, and its lower portions may still bear traces of rock art (Bednarik 1989). If a datable occupation floor could be located beneath the rock fall it would provide a maximum date for the roof fall, and help in establishing the age of the finger flutings. Other evidence relating to the minimum age of the art are the floor sediment deposits that sometimes conceal the lower part of the decorated areas, or that have rendered human access to them impossible. This

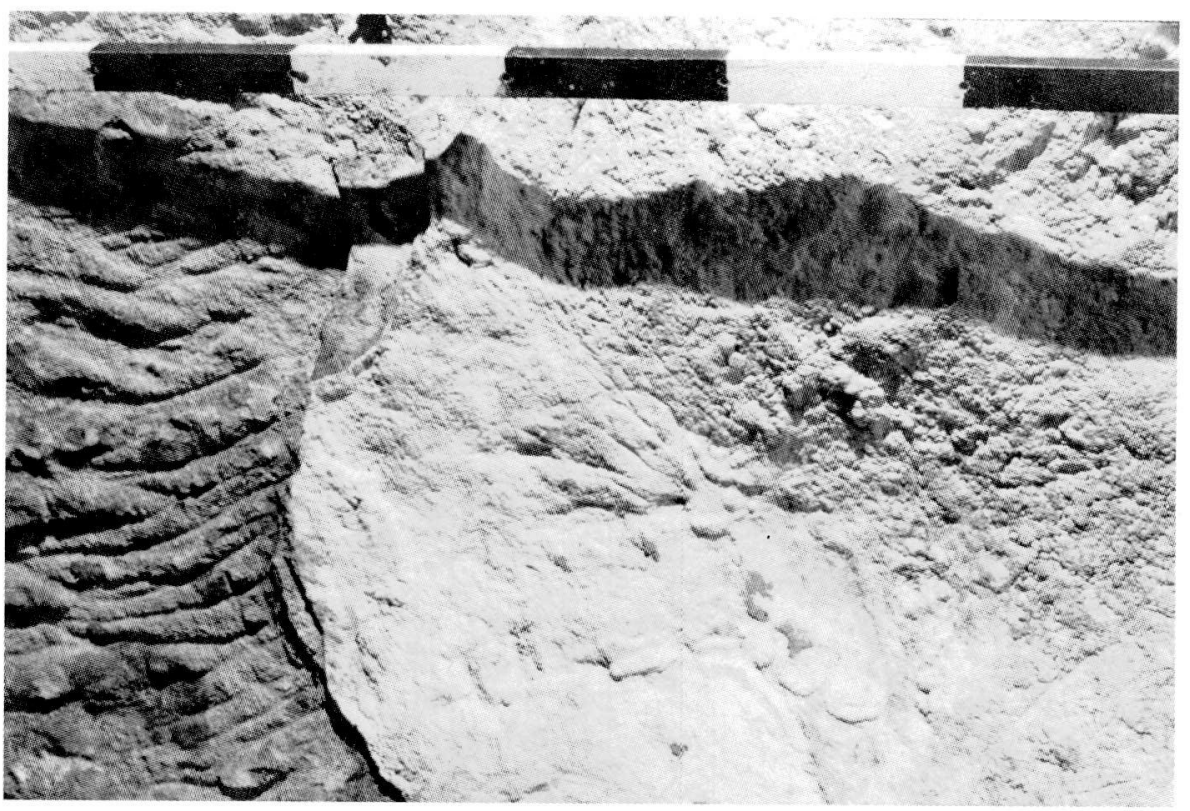

Fig.4 - Laminar cutaneous ceiling speleothem bearing mostly shallow petroglyphs on its surface, while itself covering an earlier generation of deeply carved petroglyphs which are exposed where the deposit has become exfoliated. Malangine Cave, South Australia. (Scale in dm) 
can be observed in Koongine Cave (on the east wall), as well as in other sites, such as Malangine Cave (east wall) and Orchestra Shell Cave (new part).

The relative chronological framework attempted for the petroglyphs, calcite deposits, sediments and associated lithic assemblages in Malangine Cave was the first comprehensive attempt of direct dating of rock art in the world (Bednarik 1981a, 1981b, 1993: Fig. 1). About half of the carbon contained in carbonate speleothems is derived from the atmosphere, and in most environments from respired carbon dioxide. The ${ }^{14} \mathrm{C}$ so included in reprecipitated carbonates (be they speleothems or pedogenetically derived accretions; Bednarik 1980) then decays at the known rate, enabling conventional radiocarbon dating of such deposits.

However, the ratio of carbon isotopes in reprecipitated carbonates is rather complex. To render the limestone soluble, an excess of carbon dioxide is necessary, causing less then fifty per cent of the bicarbonate's carbon to be derived from the carbonate, and thus be practically ${ }^{14} \mathrm{C}$ free. The method of estimating the proportion of ${ }^{14} \mathrm{C}$ that should have been precipitated in a stalagmite at the time of its formation was conceived by Franke (1951a, 1951b) only shortly after Libby et al.'s (1949) inauguration of the radiocarbon method. Subsequent research (Franke and Geyh 1970; Franke et al. 1958; Geyh 1969; Hendy 1969) suggests an encouraging reliability for samples from stalagmites; the duration of growth can be determined with great precision. Absolute ages have been obtained of up to 45,000 years, but they are burdened with a potential error because the initial ${ }^{14} \mathrm{C}$ concentration is not derived from the atmospheric ${ }^{14} \mathrm{C} /{ }^{12} \mathrm{C}$ ratio alone. It is clear from reaction (1) above that a surplus of carbon from the atmosphere is necessary, and while this surplus may theoretically be up to one hundred per cent (equivalent to an error of about 5000 years!) the carbon content in natural bicarbonate solutions ranges only from seventy to eighty per cent, equivalent to an error of less than 1500 years. Even this

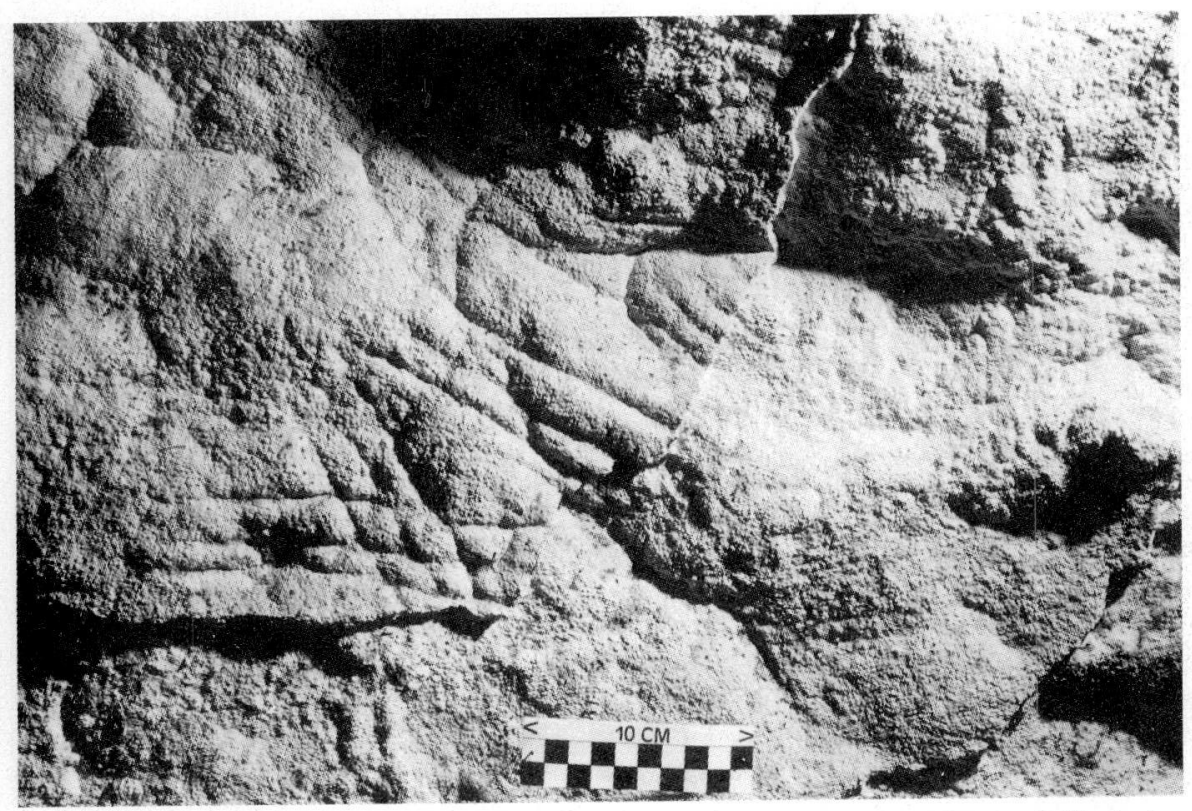

Fig.5 - The cutaneous speleothem seen on the left has exfoliated on the right, exposing the primary rock. The laminar deposit contains within it finger flutings, the course of which remained visible on the most recent surface of the deposit. Northern passage, Prung-kart Cave, South Australia. 
can be diminished dramatically if the ${ }^{14} \mathrm{C} /{ }^{12} \mathrm{C}$ ratio in the modern vadose water is determined.

However, there are still other qualifications. The most serious is the infiltration of younger vadose solution and the interstitial deposition of further calcite in the crystal lattice of the speleothem, with the resulting alteration of isotopic ratio. This possibility was initially appreciated by the European investigators, but as they limited their work to dense, crystalline stalagmites, it had little or no effect on their results. Unfortunately nearly all of the secondary carbonate deposits that can be related to rock art, be they speleothems or pedogenetic precipitates, are decidedly porous and therefore invite such deposition, and the rejuvenation it involves. In fact, we know with certainty that many of the former mondmilch bearing finger flutings became later fossilized through calcification, which means that any radiocarbon age derived from such material is effectively a minimum age, and probably quite conservative.

Another qualification refers to the past isotopic composition of atmospheric carbon, considering that plant communities have a significant effect on the $\mathrm{d}^{13} \mathrm{C}$ value of the reprecipitated carbonate: values of between -12 and $-10 \%$ o apply to respiratory carbon dioxide derived from $\mathrm{C} 3$ plants, while the $\mathrm{d}^{13} \mathrm{C}$ compositions of carbonate in equilibrium with carbon dioxide respired from $\mathrm{C} 4$ plants range from -3 to $+1 \%$ o (Cole and Monger 1994). C4 plants, so called because of the four-carbon acids as which carbon dioxide is initially captured in their outer mesophyll cells, include about half of the world's grasses, which have a physiological advantage over $\mathrm{C} 3$ plants in low atmospheric carbon dioxide concentrations (Robinson 1994). The latter are directly related to world climate, and were significantly lower during the Pleistocene glacials, as noted above. This introduces yet another variable, the effect of which is an unknown factor and questions the utility of all uncalibrated Pleistocene radiocarbon dates.

These considerations are only some of those that should temper our sometimes blind reliance on so-called scientific data. In the case of radiocarbon dating, there are others, some of which I have rehearsed elsewhere, including those of the relevant statistical constraints (Bednarik 1994c). To test the proposition of isotopic rejuvenation through calcification, and at the same time obtain the first direct data for the age of the rock art in Malangine Cave, two samples from that site were analyzed for their isotopic carbon composition in 1980. One was from the laminated and comparatively dense ceiling deposit that separates the two basic art traditions present near that site's entrance (Figure 4).

It yielded an adjusted age of $5550 \pm 55$ years BP (Hv-10241) which might be best described as a minimum mean age for the entire lamina. Cutaneous speleothems of this type require substantial time spans for their formation and, assuming a minimal postdepositional rejuvenation from younger solute, it may be that precipitation commenced some time before $6000 \mathrm{BP}$, which would provide a conservative minimum age for the deep petroglyph generation. It may be relevant that 'absolute' radiocarbon ages for several occupation deposits in the coastal region of south-eastern South Australia are from the early Holocene (Tindale 1957:110; Luebbers 1978:113-34), and therefore coincide in their magnitude with the implied age of the pre-lamina petroglyphs in Malangine Cave. Perhaps more pertinent still are the results of a later excavation of Koongine Cave, just 105 metres to the west of Malangine, which yielded a series of radiocarbon dates from sedimentary charcoal that is thought to have been introduced by human occupation (Frankel 1986). There is a concentration of early Holocene dates evident, and while this may not reflect archaeological reality or even relate to the human presence demonstrated by the rock art, there is a good possibility that some of the art of the two caves was created during that apparent occupation phase. 
The second sample processed was from the stratigraphically older, pearly deposit in the deep part of Malangine Cave, which clearly predates the deep petroglyphs and the laminated deposit formed over them but postdates the finger flutings. The radiocarbon age of $4425 \pm 75$ years BP (Hv-10240) does not contradict the result just cited, it confirms the proposition that rejuvenation can significantly affect the isotopic composition of the speleothem. The highly porous fossil mondmilch and the hard excrescence covering it have in all probability remained moist for most of their existence; the subcutaneous stratum has retained a significant content of water to the present time. The absence of any exfoliation suggests that full dehydration may have, in fact, not occurred at all. Greater moistness is apparent even in the recent past, for instance in inscriptions of only seventy years ago. Present hydrological conditions may have been influenced by the effects of pastoral land clearing, which would have led to reduced moisture conservation and lower carbon dioxide production.

A second factor may be involved in the low age of Hv-10240. The sample contained some of the brown colouring matter shown in Figure 3 which analysis has shown to be almost entirely organic (Bednarik 1994b). Since it must be radiometrically younger than the speleothem in whose pores it lodged, further rejuvenation is likely through this contamination.

More recently, another site, about $31 \mathrm{~km}$ from Malangine Cave, was subjected to a similar study. In Prung-kart Cave, finger flutings have been preserved under a laminar speleothem (a calcareous, laminated skin of reprecipitated carbonate in a cave) of 15 to $20 \mathrm{~mm}$ thickness (Figure 5).

After the natural exfoliation of almost one square metre of this deposit, caused by the fine rootlets of an exotic tree species (Pinus radiata), it was found that the cutaneous deposit consists of over a dozen distinctive laminae in section. They are alternatively white and grey layered and it was hoped that the darker layers had been caused by the deposition of organic matter during periods of higher aquifer levels. Since the finger flutings are sandwiched within this laminar deposit, it was separated into inner (older) and outer (younger) layers, and isotopic carbon was determined. The outermost portion of the speleothem skin produced a radiocarbon age of $1150 \pm 80$ years BP (ANU-6963B), the innermost was $2590 \pm 80 \mathrm{BP}$ (ANU-6963A). The dark substance, unfortunately, did not contain adequate organic matter for conventional radiocarbon dating, and accelerator mass spectrometry dating was not attempted.

The age of ANU-6963A was recalculated as ANU-6963, at $2660 \pm 70 \mathrm{BP}$, by basing the calculation on a measured $\mathrm{d}^{13} \mathrm{C}$ of $-0.8 \pm 0.1 \% \mathrm{o}$, not the estimate normally used in routine calculations $(-5.0 \pm 2.0 \% \mathrm{o})$. A further sample from the inner strata then yielded a date of $2950 \pm 70 \mathrm{BP}, \mathrm{d}^{13} \mathrm{C}$ being $-1.1 \pm 0.1 \%$ o this time (ANU-8457). The measured deviations of ${ }^{13} \mathrm{C}$ from that of standard marine limestone carbon are lower than was estimated, and much lower than in atmospheric carbon dioxide. This could suggest that the carbon active in the speleothem skin formation derives almost entirely from inorganic sources (gaseous volcanic emissions), or alternatively from C4 plants. The Mt Gambier region has been subjected to much recent volcanic activity, peaking apparently during the mid-Holocene (Blackburn 1966; Sheard 1983; Prescott 1994), and its Oligocene and lower Miocene limestones are highly porous (Bednarik 1991c reports up to $50.8 \%$ porosity by volume from Paroong Cave). The retention of gaseous cave deposits may well be facilitated by the aquifer level of the region which is frequently close to the surface (Holmes and Waterhouse 1983). For comparison, the measured $\mathrm{d}^{13} \mathrm{C}$ of the two samples of speleothem in Malangine Cave was $+0.2 \% \mathrm{o}(\mathrm{Hv}-10240)$ and $-4.8 \% \mathrm{o}(\mathrm{Hv}-$ 10241) (Bednarik 1981a), which suggests considerable fluctuation in the region.

The Prung-kart speleothems remain so porous that, without independent calibration 
(e.g. through organic matter deposited in the layers, or by uranium-thorium dating), it remains unknown how much of the deposit's crystal lattice actually predates the rock art. While the layers found above the art must postdate it entirely, a certain proportion of the deposit beneath the art may still be younger than the art. Hence radiocarbon analysis would provide only minimum values of real age, from both deposits. On the other hand, if a part of the carbon dioxide in the solution process was not of atmospheric, but of volcanic origin, as may be the case, then the dating results are likely to overestimate the age of the calcite formation by an unknown factor. In reality, the carbon dioxide may have been derived from both sources (volcanic and biological), and during deposition the relative proportions may have fluctuated through time in accordance with such factors as volcanic activity, aquifer level, ambient climate, vegetation regimes and so forth.

\section{CONCLUSION}

These considerations show us how unlikely it is that reliable dating of such reprecipitated calcareous deposits can be obtained by simple radiocarbon determination alone. Similarly, oxygen isotope analysis is not a secure means of determining formation temperature, because the level of 180 in the calcite precipitated is not a function of temperature alone; it can be influenced by kinetic isotopic fractionation (Hendy 1971). Nevertheless, both the results obtained from radiocarbon dating of reprecipitated calcite and the heuristic developments it facilitates are a significant help in attaining a better understanding of the complex world of carbonate speleothems. They may not provide us with finite answers concerning the rock art such phenomena may spatially be associated with, but they certainly help us better to focus on the issues and complex interrelationships. They also open up new avenues of future research in this complex area. For instance, the mechanisms determining the interrelationships between atmospheric carbon dioxide levels and temperatures, vegetation patterns, isotopic fractionation (and thus radiocarbon ages) and past climates can now be subjected to new scrutiny. If, as the Antarctic ice cores (Morgan 1993) suggest, there is a solid correlation between climate and carbon dioxide level, and another between carbon dioxide level and respired $\mathrm{d}^{13} \mathrm{C}$, by way of favoured plant communities, how does this affect uncalibrated radiocarbon dates? And how much influence could plant communities have on atmospheric temperature? These are contentious issues, and they are very weighty indeed. I hope to have shown in this paper that carbonate speleothems, themselves such enormously complex phenomena, are among those that can play a role in the future investigation of such important issues - issues that are not only relevant to archaeologists and rock art students, but to the human understanding of the macro-ecology of the global environment.

\section{ACKNOWLEDGMENTS}

The help of Professor M. A. Geyh, Dr Andrée Rosenfeld, Dr M. John Head, Geoffrey D. Aslin and Elfriede K. Bednarik is gratefully acknowledged.

\section{REFERENCES}

BAKER A., P.L. SMART, R. LAWRENCE EDWARDS \& D.A. RICHARDS. 1993 - Annual growth banding in a cave stalagmite. Nature 364: 518-20.

BALLARD C. 1993. First report of digital fluting from Melanesia. Rock Art Research 9: 119-21. 
BATES R. L. \& J. A. JACKSON (Eds) 1987. Glossary of Geology (3rd edn). American Geological Institute, Alexandria, VA.

BEDNARIK R.G. 1980. The potential of rock patination analysis in Australian archaeology - part 2. The Artefact 5: 47-77.

BEDNARIK R.G. 1981a. Malangine and Koongine Caves, South Australia. Unpubl. MS, 38 pp., Archive of the Australian Rock Art Research Association, Melbourne.

BEDNARIK R.G. 1981b. Finger lines, their medium, and their dating. Unpubl. MS, 34 pp., Archive of the Australian Rock Art Research Association, Melbourne.

BEDNARIK R.G. 1984. Die Bedeutung der paläolithischen Fingerlinientradition. Anthropologie 23: 73-79.

BEDNARIK R.G. 1985. Parietal finger markings in Australia. Bollettino del Centro Camuno di Studi Preistorici 22: 83-88.

BEDNARIK R.G. 1986. Parietal finger markings in Europe and Australia. Rock Art Research 3: 30-61, 15970.

BEDNARIK R.G. 1989. Perspectives of Koongine Cave and scientistic archaeology. Australian Archaeology 29: 9-16.

BEDNARIK R.G. 1990. The cave petroglyphs of Australia. Australian Aboriginal Studies 1990(2): 64-68.

BEDNARIK R.G. 1991a. On natural cave markings. Helictite 29(2): 27-41.

BEDNARIK R.G. 1991b. Comment on F. d'Errico, 'Microscopic and statistical criteria for the identification of prehistoric systems of notation’. Rock Art Research 8: 89-91.

BEDNARIK R.G. 1991c. The Paroong Cave Preservation Project. In C. Pearson and B. K. Swartz (eds.), Rock art and posterity: conserving, managing and recording rock art..Occasional AURA Publication No. 4, Australian Rock Art Research Association, Melbourne: 66-70.

BEDNARIK R.G. 1993. The calibrated dating of petroglyphs. The Artefact 16: 32-38.

BEDNARIK R.G. 1994a. The discrimination of rock markings. Rock Art Research 11(1): 23-44.

BEDNARIK R.G. 1994b. Malangine and Koongine Caves, South Australia. The Artefact 17: 43-60.

BEDNARIK R.G. 1994c - Conceptual pitfalls in Palaeolithic rock art dating. Préhistoire Anthropologie Méditerranéennes 3: 1-8.

BEDNARIK R.G. \& M.J. HEAD. 1995. Recent dating results from Australian cave petroglyphs. Rock Art Research 12.

BLACKBURN G. 1966. Radiocarbon dates relating to soil development and volcanic ash deposition in southeast South Australia. Australian Journal of Science 29: 50-52.

COLE D.R. \& H.C. MONGER. 1994. Influence of atmospheric $\mathrm{CO}_{2}$ on the decline of $\mathrm{C} 4$ plants during the last deglaciation. Nature 368: 533-36.

CRAIGH H. 1953. The geochemistry of the stable carbon isotopes. Geochimica et Cosmochimica Acta 3: 5392.

CRAIGH H. \& C.D. KEELING. 1963. The effects of atmospheric $\mathrm{N}_{2} \mathrm{O}$ on the measured isotopic compositions of atmospheric $\mathrm{CO}_{2}$. Geochimica et Cosmochimica Acta 27: 549-551.

DREYBRODT W. 1988. Processes in karst systems. Springer Verlag, Berlin.

DROUOT E. 1976. L'art pariétal paléolithique a La Baume Latrone. In H. DE LUMLEY (ed.), Provence et Languedoc Méditerranéen sites paléolithiques et néolithiques. Proceedings of the IXth Congress of the Union Internationale des Sciences Préhistoriques et Protohistoriques, Nice.

FISCHER H. 1989. Etymology, terminology, and an attempt of definition of mondmilch. National Speleological Society Bulletin 50: 54-58.

FRANKE H.W. 1951a. Altersbestimmung an Sinter mit radioaktivem Kohlenstoff. Die Höhle 2: 62-4.

FRANKE H.W. 1951b. Altersbestimmungen von Kalzitkonkretionen mit radioaktivem Kohlenstoff. Die Naturwissenschaften 38: 527-31.

FRANKE H.W. \& M.A. GEYH. 1970. Isotopenphysikalische Analysenergebnisse von Kalksinter - Überblick zum Stand ihrer Deutbarkeit. Die Höhle 21: 1-9.

FRANKE H.W., K.O. MÜNNICH \& J.C. VOGEL. 1958. Auflösung und Abscheidung von Kalk - C14Datierung von Kalkabscheidungen. Die Höhle 9: 1-5

FRANKEL D. 1986. Excavations in the lower southeast of South Australia: November 1985. Australian Archaeology 22: 75-87.

GASCOYNE M. \& H.P. SCHWARCZ. 1982. Carbonate and sulphate precipitates. In M. IVANOVICH \& R.S. HARMON (Eds), Uranium series disequilibrium applications to environmental problems. Oxford University Press, Oxford: 268-301

GEYH M.A. 1969. Isotopenphysikalische Untersuchungen an Kalksinter, ihre Bedeutung für die 14CAltersbestimmung von Grundwasser und der Erforschung des Paläoklimas. Geologisches Jahrbuch 88: $149-58$. 
GEYH M.A. \& H.W. FRANKE. 1970. Zur Wachstumsgeschwindigkeit von Stalagmiten. Atompraxis 16: 85101.

GOEDE A., D.C. GREEN \& R.S. HARMON. 1982. Isotopic composition of precipitation, cave drips and actively forming speleothems at three Tasmanian cave sites. Helictite 20: 17-27.

GOEDE A., T.C. ATKINSON \& P.J. ROWE. 1992. A giant Late Pleistocene halite speleothem from Webbs Cave, Nullarbor Plain, southeastern Western Australia. Helictite 30: 3-7.

HENDY C.H. 1969. The use of C-14 in the study of cave processes. Proceedings of the XIIth Nobel Symposium, Uppsala 1969, University of Uppsala: 419-43.

HENDY C.H. 1971. The isotopic geochemistry of speleothems. Geochimica et Cosmochimica Acta 35: 80124.

HENDY C.H. \& A.T. WILSON. 1968. Palaeoclimatic data from speleothems. Nature 216: 48-51.

HOLMES J.W. \& J.D. WATERHOUSE. 1983. Hydrology. In M. J. TYLER, C. R. TWIDALE, J. K. LING \& J. W. HOLMES (Eds.), Natural history of the South East. Royal Society of South Australia Inc., Adelaide: 49-59.

HOMANN W. 1969. Experimentelle Ergebnisse zum Wachstum rezenter Höhlenperlen. Fünfter Internationaler Kongress der Speläologie. Stuttgart.

JAMES J.M. 1991. The sulphate speleothems of Thampanna Cave, Nullarbor Plain, Australia. Helictite 29: 19-23.

KEELING C.D. 1961. The concentration and isotopic abundances of carbon dioxide in rural and marine air. Geochimica et Cosmochimica Acta 24: 277-298.

LIBBY W.F. E.C. ANDERSON \& J.R. ARNOLD. 1949. Age determination by radiocarbon content: worldwide assay of natural radiocarbon. Science 109 (2827): 227.

LUEBBERS R.A. 1978. Meals and menus: a study of change in prehistoric coastal settlements in South Australia. Unpubl. Ph.D. thesis, Australian National University, Canberra.

MOORE G.W. 1952. Speleothem - a new cave term. National Speleological Society News 10: 2.

MILLIMAN J.D. 1974. Marine carbonates. Springer Verlag, New York.

MILLS G.A. \& H.C. UREY. 1940. The kinetics of isotope exchange between carbon dioxide, bicarbonate ion, carbonate ion, and water. Journal of the American Chemistry Society 62: 1019-26.

MORGAN V. 1993. Ice core dating and climatic records. The Artefact 16: 8-11.

PRESCOTT J. 1994. TL dating of Mt Gambier volcanics. Paper presented to Fifth Australasian Archaeometry Conference, Armidale, Australia (in press).

ROBINSON J.M. 1994. Atmospheric CO2 and plants. Nature 368: 105-6.

SCHWARCZ H.P. 1980. Absolute age determination of archaeological sites by uranium series dating of travertines. Archaeometry 22: 3-24.

SHEARD M.J. 1983. Volcanoes. In M. J. TYLER, C. R. TWIDALE, J. K. LING \& J. W. HOLMES (Eds.), Natural history of the South East. Royal Society of South Australia Inc., Adelaide: 7-14

TINDALE N.B. 1957. A dated Tartangan implement site from Cape Martin, south east of South Australia. Transactions of the Royal Society of South Australia 80: 109-23.

WENDT, I., W. STAHL, M.A. GEYH \& F. FAUTH. 1967. Model experiments for ${ }^{14} \mathrm{C}$-age determinations. In: Isotopes in hydrology. Proceedings of the IAEA, Vienna: 321. 